\title{
THE EXPRESSION OF TGF- $\beta 1$ AFTER LOW LEVEL LASER THERAPY IN INFLAMMATION ANIMAL MODEL
}

\author{
Imam Subadi, Indrayuni Lukitra Wardhani, Andriati \\ Department of Physical Medicine and Rehabilitation, Faculty of Medicine, \\ Universitas Airlangga, Surabaya
}

\begin{abstract}
ABSTRAK
Nyeri merupakan keluhan yang paling sering didapatkan dalam praktek sehari-hari. Keluhan nyeri merupakan manifestasi klinik akibat rangsangan yang menimbulkan kerusakan jaringan. Terapi laser berkekuatan rendah digunakan untuk menurunkan nyeri. Salah satu indikator penyembuhan jaringan adalah aktifasi transforming growth factor- $\beta 1$ (TGF- $\beta 1$ ). Penyembuhan kerusakan jaringan akan menghilangkan nyeri. Apakah terapi laser berkekuatan rendah memicu ekspresi TGF- $\beta 1$ ? Tujuan penelitian ini adalah membuktikan ekspresi TGF- $\beta 1$ pada terapi laser berkekuatan rendah. Penelitian ini menggunakan tikus jantan strain Wistar, umur 3 bulan, berat badan antara 250 - 300 gram. Model hewan nyeri inflamasi yaitu induksi complete Freund adjuvant (CFA) 100 $\mu L$ pada telapak kaki kiri. Subyek dikelompokkan menjadi tiga kelompok yaitu KO $(n=10)$ tikus normal; K1 (n=10) tikus yang diinduksi CFA saja; P1 (n=10) tikus yang diinduksi CFA ditambah terapi laser berkekuatan rendah dengan Lasermed tipe 2100 dengan panjang gelombang $905 \mathrm{~nm}$, out put power 25 - $500 \mathrm{~mW}$ power: $30 \mathrm{~mW} / \mathrm{cm} 2$, dosis: $1 \mathrm{Joule} / \mathrm{cm} 2 ; 5 \mathrm{kali}$ dengan interval 24 jam pada telapak kaki kiri. Sampel diambil dari kulit telapak kaki kiri dan dilakukan pemeriksaan imunohistokimia dengan antibodi monoklonal anti TGF- $\beta 1$. Penghitungan dilakukan terhadap sel yang imunoreaktif tercat coklat pada sel makrofag. Data dianalisis menggunakan uji Games Howell dengan perangkat lunak SPSS 17. Terdapat perbedaan yang signifikan ekspresi TGF- 1 pada kelompok terapi laser berkekuatan rendah $(15,8 \pm 3,1)$ terhadap kelompok kontrol positif $(3,9 \pm 1,1)$ dan terhadap kelompok kontrol negatif $(4,6 \pm 2,1), p \leq 0,05$. Tidak ada perbedaan yang bermakna antara kelompok kontrol negatif dan kelompok kontrol positif. Disimpulkan bahwa terapi laser berkekuatan rendah meningkatkan ekspresi TGF-ß1. (FMI 2017;53:29-32)
\end{abstract}

Kata kunci: laser berkekuatan rendah, TGF- $\beta 1$

\begin{abstract}
Pain is the most common complaints in everyday practice. Pain is a clinical manifestation caused by stimuli due to potential tissue damage. Low level laser therapy (LLLT) has been used in reducing pain. One of indicator tissue healing is activation of transforming growth factor $-\beta 1(T G F-\beta 1)$. Tissue healing will eliminate the pain. Do LLLT stimulate TGF- $\beta 1$ expression? The objective of this study was to investigate the expression of TGF- $\beta 1$ in low level laser therapy. Thirty male Wistar rats, body weight $250-300$ gram, 3 month old, were divided into 3 groups, negative control $(n=10)$, positive control $(n=10)$ and treatment groups $(n=10)$. The positive control and treatment groups were injected with Complete's Freund Adjuvant (CFA) $100 \mu \mathrm{L}$ at left footpad. The treatment group treated with low level laser therapy Lasermed type 2100 wavelength $905 \mathrm{~nm}$, out power 25-500 $\mathrm{mW}$, dose 1 joule/cm2;5 times with interval 24 hours on left footpad. Samples were taken from the skin of footpad and immunohistochemical examination with monoclonal antibody anti-TGF- $\beta 1$. Calculations carried out on brown reaction in macrophage cell. Data were analyzed using the Games Howell with SPSS 17. There were significant differences in the expression of TGF- $\beta 1$ in treatment group (15.8 \pm 3.1 ) compared with the positive control group $(3.9 \pm 1.1)$ and negative control group (4.6 \pm 2.1$)$. There were no significant differences between expression TGF- $\beta 1$ in positive control group and negative control group. In conclusion, low level laser therapy increased the expression of TGF- $\beta 1$. (FMI 2017;53:29-32)
\end{abstract}

Keywords: Low level laser therapy, TGF- $\beta 1$

Correspondence: Imam Subadi, Department of Physical Medicine and Rehabilitation, Faculty of Medicine, Universitas Airlangga, Dr Soetomo Hospital, Jalan Prof Moestopo 6-8, Surabaya 60286, Indonesia.

\section{INTRODUCTION}

Pain is the most complaint in everyday practice. The prevalence of chronic pain in Europe was $19 \%$ (Breivik, 2006), United State $30.7 \%$ (Johannes, 2010), while in Hong Kong 34.9\% (Wong, 2011). According WHO, the prevalence of chronic pain in developing countries $41 \%$
(Croft, 2010). Pain restrict activities daily living and cause disabilities. The economical impact of pain due to loss of productive time, was estimated 61.2 billion dollars annually (Reyes-Gibby, 2008). Reducing pain as soon as possible is very important. The most common treatment used for pain relief currently is non-steroid anti-inflammatory drugs (NSAIDs) (Buvanendran, 
2010), but NSAIDs caused serious effect such as gastric bleeding (Fujimori, 2010). Besides drugs, pain can be attenuate by heat therapy, water therapy and electrical therapy but all the treatment are still not satisfactory. Lately, low level laser therapy (LLLT) effectively reduce pain. Hegedus (2009) reported that LLLT reduced pain and improved microcirculation in patients with knee osteoarthritis. The hypothesis proposed that photon emitted LLLT captured mainly in mitochondrial cytochrome c oxidase causing a cascade cause biostimulation cell (Avci, 2013). In previous study, we found that LLLT increased HSP 70 and opioid receptor expression. The expression of opioid receptor inhibit neurotransmitter glutamate, so reduced pain.

Tissue repair is an interactive process, involving chemical mediators, cells, and the inflammatory response, characterized by the classic steps of repair: inflammation, granulation, and remodeling. The clinical efficacy of LLLT in wound healing has been reported. It has been found to significantly decrease area of wound healing (Kajagar, 2012). In proliferation phase in wound healing, transforming growth factor- $\beta 1$ (TGF- $\beta 1$ ) play an important role (Amid, 2014). TGF- $\beta 1$ acts as a regulator of growth and differentiation of cells, as well as playing an important role in the formation of the extracellular matrix (Colombo, 2013). Cell studies with cultured human keratinocytes, endothelial cells, and fibroblast indicated potential effects of near-infrared light in the treatment pf chronic skin ulcers. After irradiation of cells, the production of transforming growth factor $\beta 1$ (TGF- $\beta 1$ ) and matrix metalloproteinase-2 (MMP-2) was examined by immunoassay, zymography, and reverse transcription polymerase chain reaction (PCR). A biostimulatory effect of near-infrared irradiation was shown by significant elevation of TGF$\beta 1$ and MMP-2. Irradiated fibroblast also showed an upregulated amount of MMP-2 mRNA. These results suggest that near-infrared irradiation may accelerate wound closure (Beckman, 2014). In this study, we used an inflammatory pain animal model to know the expression TGF- $\beta 1$ during inflammatory response.

\section{MATERIALS AND METHODS}

The present study is a randomized post test control group design. Adult male Wistar rats weighing 250-300 g, 3 month old were puschased from Department of Farmacology Faculty of Medicine Universitas Airlangga. There were housed 4-5 per cage with food pellets and water ad libitum for 7 days after their puschase, thereafter they were used for experiments. During the entire study, all rats were kept in an environment with a cycle of $12 \mathrm{~h}$ light and 12 dark. Rats were kept at room temperature $(22 \pm 10 \mathrm{C})$. Study protocol has been approved by ethic committee of Faculty of Veterinary Medicine, UniversitasAirlangga, Surabaya, Indonesia (Ethics No. 504-KE).

In order to know the LLLT effects, 30 rats were randomly divided into three groups: negative control group (without any intervension), positive control group (CFA only) and treatment group. $100 \mu \mathrm{L}$ CFA was injected into the ventral surface of the left foot centered in the footpad of rats in positive control group and treatment group. In treatment group, 48 hours after CFA's injection treated with low level laser therapy Lasermed type 2100 wavelength $905 \mathrm{~nm}$, out power 25$500 \mathrm{~mW}$, dose 1 joule/cm2 for 5 times with interval 24 hours.

The expression of TGF- $\beta 1$ were tested by immunohistochemistry method using antibody monoclonal anti TGF$\beta 1$. Macrophages that produce brown color against monoclonal antibody anti TGF- $\beta 1$ are positive reaction. Positive cells for TGF- $\beta 1$ expressions were counted by using light microscope (Olympus CX21, New York, USA) at 20 microscopic fields of 1000 magnification. Kolmogorov-Smirnov test was used to check normality of all data. All data were normally distributed ( $p>0.05)$. Homogeneity data with Levene's test showed that TGF$\beta 1$ data were not homogen. Therefore Games-Howell was used to compare between negative control, positive control and treatment group for the expression of TGF$\beta 1$. Statistic package SPSS 17 was used.

\section{RESULTS}

Immunohistochemical staining showed elevated numbers of macrophage give a brown color reaction against anti-TGF- $\beta 1$ antibody subjected to LLLT, compared with the positive control groups (figure 1).

Table 1. Number of macrophages that expressed anti TGF- $\beta 1$

\begin{tabular}{|c|c|c|c|c|c|}
\hline \multirow[b]{2}{*}{ Groups } & \multicolumn{4}{|c|}{ TGF-b1 } & \multirow{2}{*}{$\begin{array}{c}\text { Games } \\
\text { Howell } \\
\text { (p) }\end{array}$} \\
\hline & $\mathrm{X}$ & $\mathrm{SD}$ & Min & $\operatorname{Max}$ & \\
\hline Negative control & $4.6^{\mathrm{a}}$ & 2.1 & 2 & 9 & \\
\hline Positive control & $3.9^{\mathrm{a}}$ & 1.1 & 2 & 6 & $\mathrm{p}<0.001$ \\
\hline Treatment & $15.8^{\mathrm{b}}$ & 3.1 & 11 & 21 & \\
\hline
\end{tabular}

Table 1 showed that there were no significant different between negative control group and positive control group. There were significant defferent between positive control group and treatment group. These result showed that LLLT enhance the expression of TGF- $\beta 1$. 

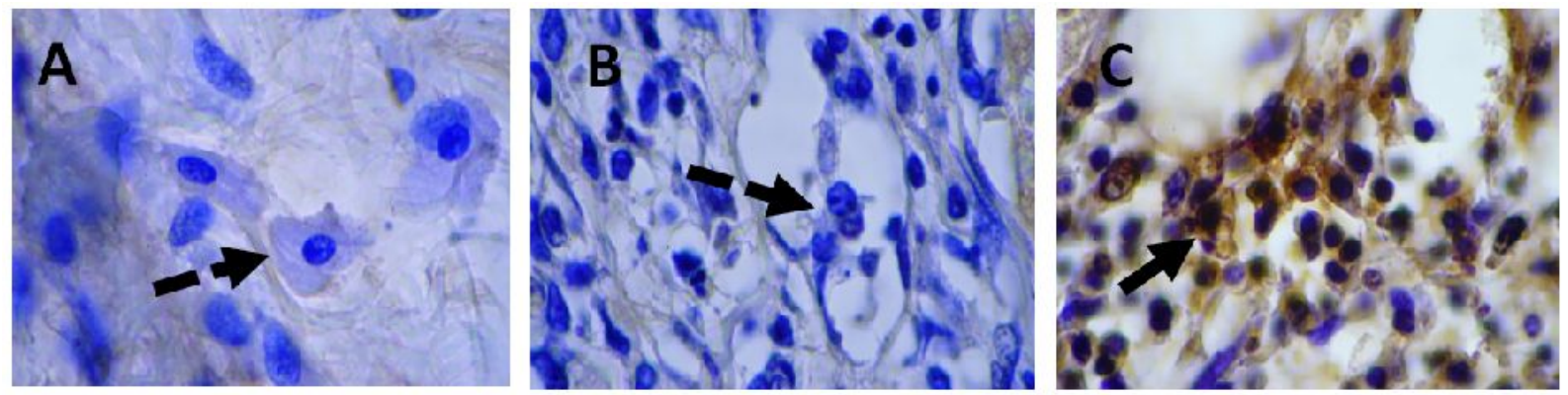

Fig. 1. Immunohistochemestry skin tisssue of the foot using monoclonal antibody anti TGF- $\beta 1$ at negative control (A), positive control (B) and treatment control (C). The magnification is 400 times, with a light microscope and camera Nikon E 100 .

\section{DISCUSSION}

In the field of medical rehabilitation, low level laser therapy was used to reduce pain. According to the International Association for the Study of Pain (IASP) pain is defined as the experience of sensation and emotional discomfort associated with apparent tissue damage or potential damage or described in terms of damage (Turk and Okifuji, 2010; King and Dougherty, 2011), Animal used to inflammatory pain model was rats induced by CFA (Zhang, 2011). This LLLT was gallium arsenide with a wavelength of $830 \mathrm{~nm}$, a dose of 1 Joule/cm2. In the last study we found the expression of HSP 70 and mu opioid receptors (Subadi I, 2014) after LLLT. Induction CFA in experimental animal cause inflammation. In the inflammatory phase of a healing process increase reactive oxygen species (ROS) and activate of NFkB expression, a transcription factor that is responsible for pro-inflammatory mediators such as interleukin and TNF- $\alpha$, growth factors, chemokines and adhesion molecules (Assiss, 2012).

One of the growth factors, namely TGF- $\beta$ plays an important role in the proliferation and migration of fibroblasts, and increasing collagen synthesis and breakdown of extracellular matrix. On the other hand, a LLLT is effective in reducing inflammation and decreased the expression of IL-1 $\beta$, IL- 6 and TNF- $\alpha$ (Alves, 2013).TGF- $\beta 1$ was the most responsible for prolifera-tion phase.

In this study, LLLT enhance TGF- $\beta 1$ in the treatment group (15.8 \pm 3.1$)$ compared to the positive controls $(3.9 \pm 1.1)$ and negative controls $(4.6 \pm 2,1)$. There was no differences between positif and negative control group. It can be concluded that the inflammatory process induced by CFA did not cause the expression of TGF$\beta 1$ and LLLT significantly increased the expres-sion of TGF- $\beta 1$. The weakness of this study is the small sample. Saafan et al (2013) using a low power laser diode (LPDL) with a wavelength of $810 \mathrm{~nm}, 200 \mathrm{~mW}$ power output, duration of therapy to 80 seconds, the power density of $0.2 \mathrm{~W} / \mathrm{cm} 2$, the energy density of 16 $\mathrm{J} / \mathrm{cm} 2$, gain increased TGF- $\beta 1$, Colombo (2013) using a laser wavelength of $660 \mathrm{~nm}, 16 \mathrm{~mW} 10 \mathrm{~J} / \mathrm{cm} 2$, do not get increased expression of TGF- $\beta 1$. Humblin et al (2006) report that administration of a low power laser therapy led to increased production of growth factors TGF- $\beta 1$ that responsible for inducing the synthesis of collagen from fibroblasts. Increased synthesis of TGF- $\beta$ are important in tissue repair. Beckmann et al (2014) conducted a systematic literature review of the 1764 article and concluded that in studies with cell and animal shows cell migration, fibroblast proliferation, rapid formation of new tissue, increased microcirculation and anti-inflammatory effect by inhibition of prostaglandin, interleukins and cytokines and bacterial effect by inducing reactive oxygen species (ROS) after LLLT. The majority of studies show benefit for diabetic wound healing.

\section{CONCLUSION}

Low level laser therapy stimulate the expression of TGF- $\beta 1$ on an animal model of inflammation pain.

\section{REFERENCES}

Alves ACA, Vieira RP, Leal ECP, Santos SA, Ligeiro AP, Albertini R et al (2013). Effect of low level laser therapy on the expression of inflammatory mediators and on neutrophils and macrophages in acute joint inflammation. Arthritis Research \& Therapy 15, 1-11.

Amid R, Kadkhodazadeh M, Ahsaie MG and Hakakzdeh A (2014). Effect of low level laser therapy on proliferation and differentiation of the cells contributing in bone regeneration. Journal of Lasers in Medical Sciences 5(4), 163-2014. 
Avci P, Gupta A, Sadasivam M, Vecchio D, Pam Z, Pam N \& Hamblin MR (2013). Low-Level Laser Therapy (LLLT) in Skin: Stimulating, Healing, Restoring. Seminars in Cutaneous Medicine and Surgery 32, 41-52.

Beckman KH, Meyer-Hamme G, and Schroder S (2014). Low Level Laser Therapy for treatment of Diabetic Foot Ulcers: A critical survey. EvidenceBased Complementary and Alternative Medicine 2014, 1-9.

Breivik H, Collett B, Ventafridda V, Cohen R and Gallacher D (2006). Survey of chronic pain in Europe: Prevalence, impact on daily life, and treatment. European Journal of Pain 10, 287-333.

Buvanendran A and Lipman AG (2010). Nonsteroidal anti-inflammatory drugs and acetaminophen. In: Fishman SM, Ballantyne JC, Rathmell JP (eds). Bonica's Management of Pain, 4th ed., Philadelphia, Wolter Kluwer - Lippincott Williams and Wilkins, $p$ 1157-1171.

Croft P, Blyth FM and Windt D (2010). The global occurence of chronic pain. In: Croft P, Blyth FM and Windt D (eds). Chronic Pain Epidemiology. New York, Oxford University Press, p 9-18.

Fujimori S, Gudis K. and Sakamoto C (2010). A review of Anti-Inflammatory Drug-Induces Gastrointestinal Injury. Pharmaceuticals 3, 1187-1201.

Hamblin MR and Demidova TN (2006). Mechanism of low level light therapy. Proc.of SPIE 6140, 1-12.
Hegedus B, Viharos L, Gervain M \& Galfi M (2009). The Effect of Low-Level Laser in Knee Osteoarthritis: A Double-Blind, Randomized, Placebo-Controlled Trial. Photomedicine and Laser Surgery 27(4), 577584.

Johannes CB, Lee TK, Zhou X, Johnston JA and Dworkin RH (2010). The Prevalence of Chronic Pain in United States Adult: Result of Internet-Based Survey. The Journal of Pain 11, 1230-1239.

Kajagar BM, Godhi AS, Pandit A, Khatri S (2014). Efficacy of Low Level Laser Therapy on Wound Healing in Patients with Chronic Diabetic Foot Ulcers. Indian Journal Surgery 74 (5), 359-363

Reyes-Gibby C, Torres-Vigil I and Croock R (2008). Epidemiology of chronic pain: classical to molecular approaches to understanding the epidemiology of pain. In: Wilson PR, Watson PJ, Haythornthwaite JA and Jensen TS (eds). Chronic Pain, 2nd ed., London, Hodder Arnold, p 65-75.

Turk DC and Okifuji (2010). Pain term and taxonomies of pain. In: Fishman SM, Ballantyne JC and Rathmell JP (eds). Bonica's Management of Pain, 4th ed., Philadephia, Lippincott William and Wilkins, p 13-23.

Wong WS and Feilding R (2011). Prevalence and Characteristics of Chronic Pain in the General Population of Hong Kong. The Journal of Pain 12, 236-245.

Zhang RX and Ren K (2011). Animal Models of Inflammatory Pain. In: Ma C and Zhang (eds). Animal Models of Pain. New York, Humana Press, p 23-40. 